\title{
Roles of mitogen-activated protein kinases and angiotensin II in renal development
}

\author{
A.P.C. Balbi ${ }^{1}$, H.D.C. Francescato ${ }^{1}$, E.C.S. Marin ${ }^{1}$, R.S. Costa ${ }^{2}$ and T.M. Coimbra ${ }^{1}$ \\ 1Departamento de Fisiologia, ${ }^{2}$ Departamento de Patologia, Faculdade de Medicina de Ribeirão Preto, \\ Universidade de São Paulo, Ribeirão Preto, SP, Brasil \\ Correspondence to: T.M. Coimbra, Departamento de Fisiologia, FMRP, USP, Av. Bandeirantes, 3900, \\ 14049-900 Ribeirão Preto, SP, Brasil \\ Fax: +55-16-3633-0017. E-mail: tmcoimbr@fmrp.usp.br
}

\begin{abstract}
Experimental and clinical evidence suggests that angiotensin II (AII) participates in renal development. Renal All content is several-fold higher in newborn rats and mice than in adult animals. All receptors are also expressed in higher amounts in the kidneys of newborn rats. The kidneys of fetuses whose mother received a type 1 All receptor $\left(\mathrm{AT}_{1}\right)$ antagonist during gestation present several morphological alterations. Mutations in genes that encode components of the renin-angiotensin system are associated with autosomal recessive renal tubular dysgenesis. Morphological changes were detected in the kidneys of 3-weekold angiotensin-deficient mice. Mitogen-activated protein kinases (MAPKs) are important mediators that transduce extracellular stimuli to intracellular responses. The MAPK family comprises three major subgroups, namely extracellular signal-regulated protein kinase (ERK), c-jun N-terminal kinases (JNK), and p38 MAPK (p38). Important events in renal growth during nephrogenesis such as cellular proliferation and differentiation accompanied by apoptosis on a large scale can be mediated by MAPK pathways. A decrease in glomerulus number was observed in embryos cultured for 48 and $120 \mathrm{~h}$ with ERK or p38 inhibitors. Many effects of All are mediated by MAPK pathways. Treatment with losartan during lactation provoked changes in renal function and structure associated with alterations in $A T_{1}$ and type 2 All $\left(A T_{2}\right)$ receptors and p-JNK and p-p38 expression in the kidney. Several studies have shown that All and MAPKs play an important role in renal development. However, the relationship between the effects of All and MAPK activation on renal development is still unclear.
\end{abstract}

Key words: Renal development; Angiotensin II; Mitogen-activated protein kinase; Angiotensin II antagonists; Sodium intake

Presented at the IV Miguel R. Covian Symposium, Ribeirão Preto, SP, Brazil, May 23-25, 2008.

Research supported by FAPESP (\#06/57015-6). A.P. Coelho Balbi and E.C.S. Marin are recipients of FAPESP fellowships (\#02/ 04457-0 and \#07/55816-4). H.D.C. Francescato, R.S. Costa and T.M. Coimbra are recipients of CNPq fellowships (\#500047/ 2003-0 and \#155068/2006-7).

Received July 2, 2008. Accepted December 16, 2008

\section{Introduction}

In humans, the branching ureteric duct reaches the outer cortex approximately 12 weeks before term. New nephron formation ceases between the 28th and 36th gestational week (1). The nephrogenesis of rats begins on embryonic day 12 and is completed between 10 and 15 days after birth (1,2). Four different stages of glomerular development have been defined: a) vesicle, b) S-shaped body, c) developing capillary loop, and d) maturing stages (2). One- and 7-day-old rats present glomeruli in different stages of differentiation, while 15- and 30-day-old rats present glomeruli in the final stage of development.

Increases in fibronectin, $\alpha$-smooth muscle actin ( $\alpha$-SMactin), proliferating cell nuclear antigen (PCNA), phosphoextracellular signal-regulated protein kinase ( $p$-ERK), and angiotensin II (AII) expression are observed in the renal cortex of 1- and 7-day-old rats, followed by a decrease during renal development (3). The activation of these cells may be due at least in part to an increase in renal All and mitogen-activated protein kinase (MAPK) content in the renal cortex (Figure 1). Fibronectin is one of the most 
important components of the extracellular matrix (ECM). Formation of the ECM represents a key event in kidney cell differentiation $(4,5)$. Fibronectin is a glycoprotein that can interact with some proteins from the cell or ECM, inducing changes in cellular migration and adhesion (5). All stimulates mesangial cells to produce various ECM components in cell culture studies (6), and also promotes cell proliferation and differentiation (7). It has also been shown that human fetal mesangial cells express $\alpha$-SM-actin $(8,9)$ and that large-scale cell proliferation occurs during kidney development (10). Up-regulated $\alpha$-SM-actin synthesis by mesangial cells is frequently associated with increased cell proliferation and ECM production (11).

ERK has been related to cell proliferation and differentiation and is also expressed at higher intensity in 1-dayold rats $(12,13)$. Several effects of All are mediated through MAPK pathways $(14,15)$. Kubo et al. (14) reported that All and endothelin provoke increased MAPK activity in cultures of vascular smooth muscle cells, and that this activity
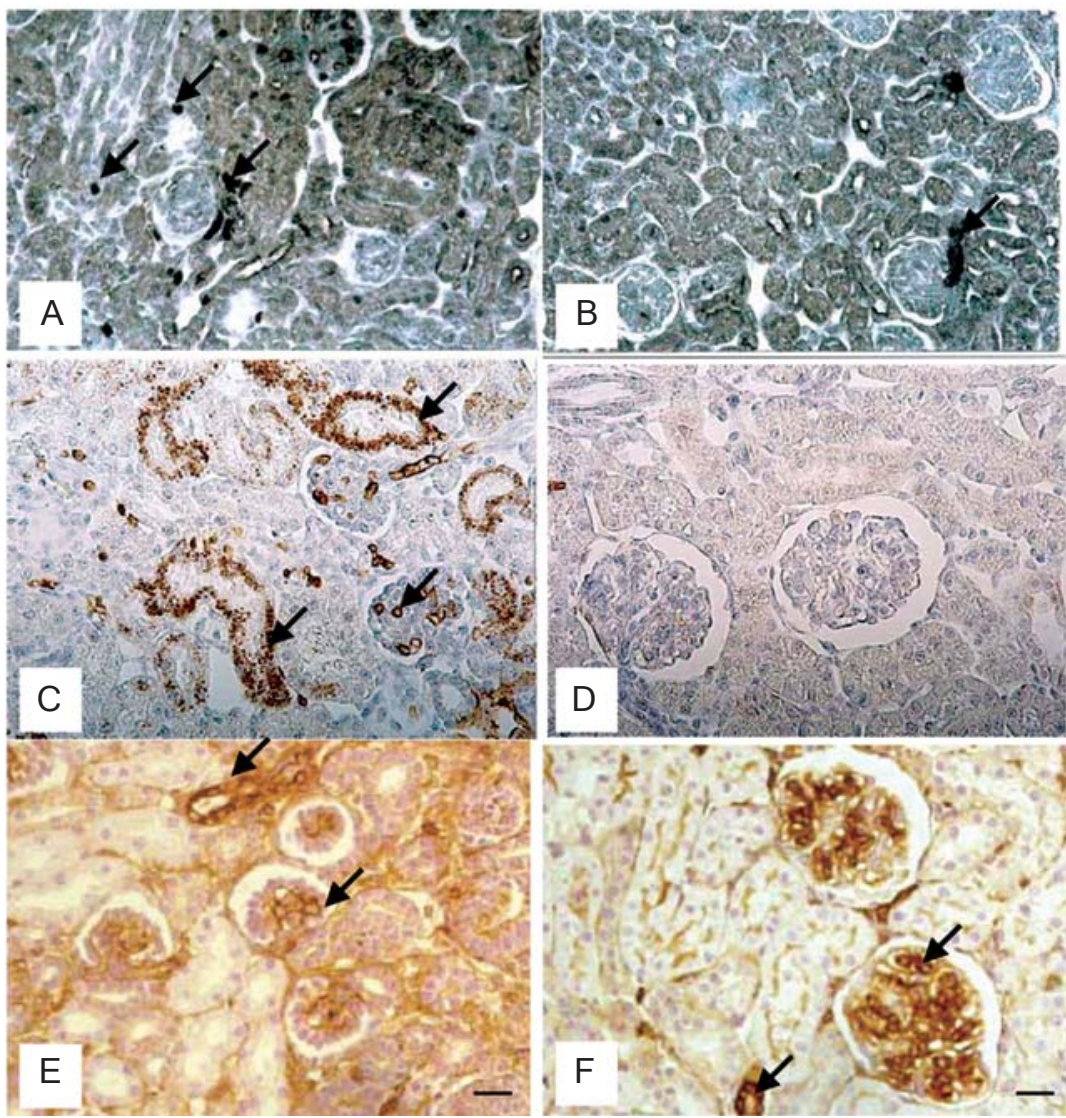

Figure 1. Immunolocalization of angiotensin II (A and B), phospho-extracellular signalregulated protein kinase ( $p$-ERK; $C$ and $D)$, phospho-c-jun N-terminal kinase ( $p$-JNK; $E$ and $F$ ) (arrows) in the renal cortex of rats at $1(A, C$, and $E$ ) and 30 days (B, D, and F) of age (scale bars $=20 \mathrm{~mm}$; original magnification 250X). Note that the reactions are more intense in $A$ and $C$ than in $B$ and $D$. is inhibited by losartan and by an endothelin receptor antagonist. In addition, evidence shows that MAPK expression in the developing kidneys is modulated by angiotensin-converting enzyme, and that c-Jun N-terminal kinases (JNKs), as well as All-related intracellular signaling pathways of renal apoptosis in the developing kidney can be mediated by the p38 MAPK pathway (15). Taken together, the results of all these studies show that All plays an important role in renal development and that many effects of this peptide, such as cell proliferation and differentiation as well as apoptosis, can be mediated by the MAPK pathways.

\section{Evidence for a role of All in kidney development}

Clinical and experimental evidence shows that the renin-angiotensin system participates in renal development (16-22). Greater angiotensinogen expression has been observed in the rat kidney during late gestation and the newborn period than in adult kidney. Renin mRNA was detected after embryonic day 17 and was higher in fetuses on embryonic day 20 and in newborns than in adult rats $(17,18)$. Renal All content is several-fold higher in newborn rats and mice than in their adult counterparts. All receptors are also expressed to a greater extent in newborn rats (19). The mRNA for the type 1 All receptor $\left(A T_{1}\right)$ has been detected in the renal glomeruli of newborn rats during cell proliferation and differentiation (20). Renal expression of the type 2 All receptor $\left(\mathrm{AT}_{2}\right)$ increases during fetal life and decreases after birth (20), suggesting that All modulates the growth of various cell types and tissues $(21,22)$.

Mutations in genes that encode components of the renin-angiotensin system are associated with autosomal recessive renal tubular dysgenesis (23). Kidneys from fetuses with tubular dysgenesis show absence of tubule differentiation and marked thickening of arterial walls. These fetuses also present anuria, oligohydramnios and skull ossification defects. The kidney of 3-weekold angiotensin-deficient mice showed pelvic dilation with an atrophic papilla, 
medial hyperplasia of the interlobular artery and afferent arterioles, glomeruli with axial mesangial expansion, reduced glomerular area, patchy fibrosis, mononuclear infiltrate in the interstitium, as well as dilated tubules in the outer medulla with interstitial fibrosis around the dilated tubules (24). In conclusion, several lines of clinical and experimental evidence indicate that All has an important role in pre- and postnatal renal development.

\section{Evidence for the role of MAPK in kidney development}

Many effects of All are mediated through MAPK pathways $(14,15,25)$. All converting enzyme modulates the expression of components of the MAPK family in kidney from neonatal rats (15). Kumar et al. (25) suggested that the activation of p38 and JNK MAPKs was linked to All signaling and demonstrated that such activation is associated with acute ischemic-reperfusion injury and may be linked, in part, to $\mathrm{AT}_{2}$ stimulation. The authors showed that the improvement in left ventricular function induced by $\mathrm{AT}_{2}$ blockade was associated with a normalized expression of p-JNK-1 and a slight increase in p38 expression.

Immunoblot analyses of kidney homogenates, as well as immunohistochemical studies, have indicated that ERK and p38 MAPKs are predominantly expressed in the developing kidney, the highest levels being observed in the embryo (10). The role of JNK MAPK in embryogenesis has been investigated, and it has been shown that the loss of the MKK4 gene, a JNK activator, results in embryonic death (26). A decrease in glomerulus number was observed in 15-day-old embryos cultured for 48 and $120 \mathrm{~h}$ with ERK or p38 inhibitors (27). Choi et al. (15) reported that the treatment of newborn rats with enalapril for 7 days increased JNK-2 and p38 MAPK expression in the kidney, and that these increases were temporally associated with higher numbers of apoptotic cells. However, the authors did not find any alteration in renal $\mathrm{p}$-ERK expression in those animals. Nevertheless, it has been previously shown that $\mathrm{p}$-ERK is related to cell proliferation and differentiation, while p-JNK and p38 MAPKs are in- volved in apoptosis (28). Therefore, the activation of the MAPK pathways by All can result in apoptosis and cell proliferation and differentiation that are important events in renal development (Figure 2).

\section{Renal development in offspring of dams submitted to a high sodium diet during pregnancy}

It has been reported that a prenatal high salt diet increases blood pressure and salt retention in spontaneously hypertensive rats (29). da Silva et al. (30) and Hazon et al. (31) observed that adult offspring submitted to perinatal salt overload presented higher blood pressure, which was associated with increased renal All content and absence of plasma renin changes in response to higher salt consumption (30). We observed a decrease in fibronectin, $\alpha$-SM-actin, PCNA, p-ERK MAPK, AT 1 , and All expression in the renal cortex of 1-day-old pups from dams subjected to sodium intake compared to same-age control rats $(3,13)$. Therefore, there is a temporal association between the

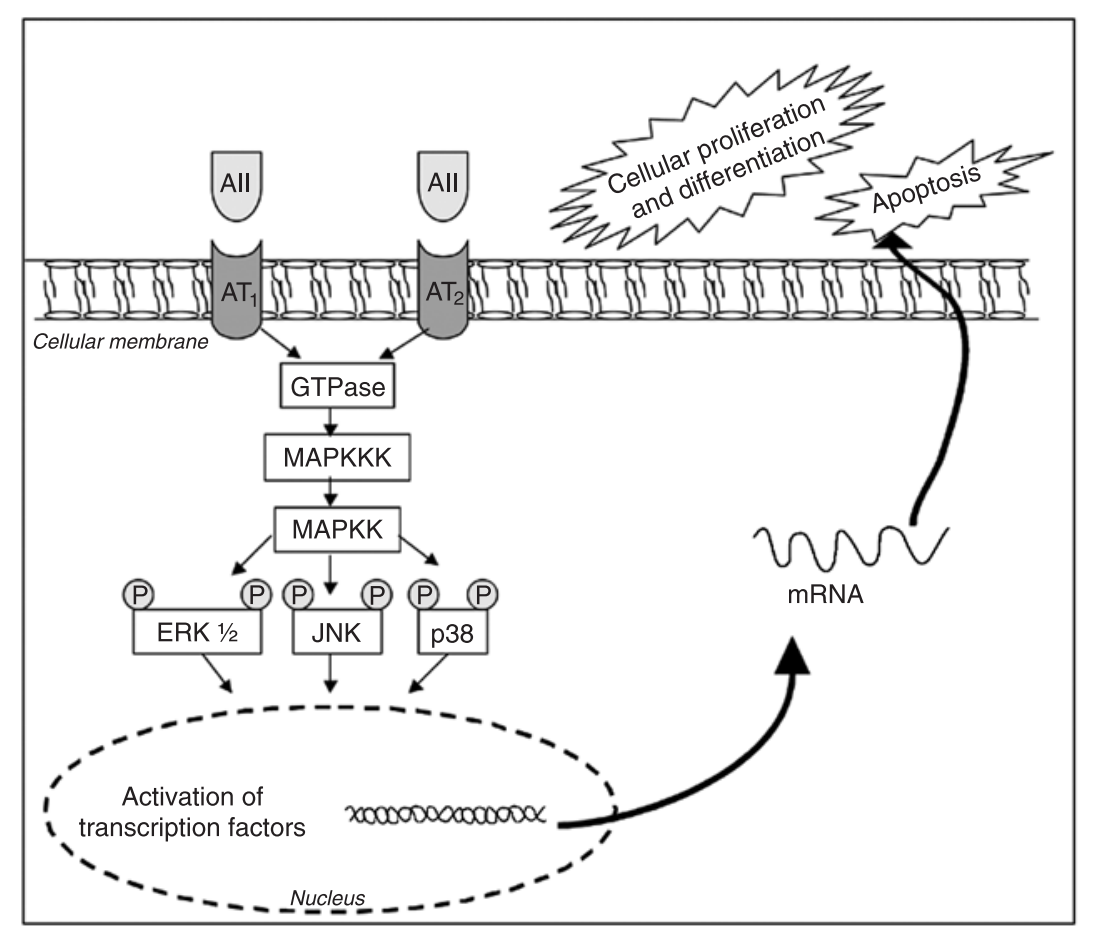

Figure 2. Schematic representation of angiotensin II (All)-induced mitogen-activated protein kinase (MAPK) activation. All acts through the type 1 All $\left(A_{1} T_{1}\right)$ and type 2 All $\left(\mathrm{AT}_{2}\right)$ membrane receptors initiating intracellular signaling, with MAPK phosphorylation and activation of transcription factors in the nucleus, resulting in mRNA production for mediators of apoptosis, cellular differentiation and proliferation. GTPase $=$ guanosine triphosphatase; MAPKKK = MAPKK kinase; $M A P K K=$ MAPK kinase; ERK = extracellular signal-regulated protein kinase; JNK = c-jun N-terminal kinase; p38 = p38 MAPK. 
reduction of All and p-ERK MAPK expression and the decrease of $\alpha$-SM-actin, fibronectin and PCNA expression in the renal cortex. There was an increase in p-p38 and pJNK MAPK expression in 30-day-old pups of dams that received sodium intake (13).

Thirty-day-old rats from dams that received saline also presented higher systolic blood pressure and a decrease in glomerular filtration rate (3). We also found increased glomerulosclerosis and tubulointerstitial lesions in the renal cortex of 120-day-old offspring from dams subjected to an increase in saline intake compared to the same age control rats (32). These data show that sodium intake during gestation and lactation in rats leads to changes in the renal expression of All receptors and MAPK in the pups that result in higher blood pressure and structural changes in the kidney of adult offspring.

\section{Renal development in offspring of mothers that received angiotensin II antagonists}

Human fetal kidneys from mothers that received an $\mathrm{AT}_{1}$ antagonist during gestation presented poorly developed tubules, increased mesenchymal tissue, reduced numbers of proximal tubules, abnormal arterial and arteriolar walls, poorly developed vasa recta, and hyperplastic juxtaglomerular apparatus (33). Spence et al. $(34,35)$ have shown in experimental studies that maternal treatment with losartan during late gestation and lactation is associated with lower pup body weights and higher pup mortality rates during the preweaning/postweaning periods, as well as irreversible histopathologic renal abnormalities in the F1 generation. Morphological renal findings, such as dilation of the renal pelvis, edema of the renal papilla, medial hypertrophy of intracortical arterioles, chronic renal inflammation, and irregular scarring of the renal parenchyma, have been described in rats. Akil et al. (36), using losartan to block $A T_{1}$ in pregnant rats, observed that the fetuses presented growth inhibition, delayed nephron maturation, increased TGF- $\beta$ immunoreactivity and glomerular basal membrane thickness associated with apoptosis in devel- oping tubular structures during the early period of nephrogenesis. It was also reported that the fibrogenic effects of All were mediated by $\mathrm{AT}_{2}$ receptors whose expression was increased in injured tissues and organs undergoing remodeling.

Neonatal rats treated with an angiotensin-converting enzyme inhibitor presented persistent and irreversible histopathological renal abnormalities in adult life (37). These abnormalities mainly consisted of cortical tubulointerstitial inflammation, various degrees of papillary atrophy and pelvic dilation.

Chen et al. (38) reported in rat pups treated for 2 days with losartan down-regulation of genes encoding cytoskeletal and ECM components, resulting in malformation of the ECM and dysfunction of cell-cell and cell-matrix interactions. Machado et al. (39) observed that rats that received losartan during lactation presented albuminuria and alterations in renal structure in adult life that were related to the presence of an inflammatory infiltrate in the renal cortex. We observed that the 30-day-old pups from dams treated with losartan during lactation presented increased $A T_{2}$, pJNK and p-p38 expression in the kidneys and higher numbers of TUNEL (apoptosis) and PCNA-positive cells in the renal cortex (40). Albuminuria, decreased glomerular filtration rate as well as tubulointerstitial alterations and decreased glomerular area were also found in 30-day-old offspring from losartan-treated dams. Taken together, these data show that treatment with losartan during lactation can provoke changes in renal function and structure in rats associated with alterations in $\mathrm{AT}_{1}, \mathrm{AT}_{2}, \mathrm{p}-\mathrm{JNK}$ and p-p38 expression in the renal cortex. However, the effects of All on MAPK activation in the kidney of pups that received losartan during lactation have not yet been clarified.

\section{Acknowledgments}

The authors are grateful to Cleonice G.A. da Silva, Adriana L.G. de Almeida, Erica Delloiagono, and Rubens Fernando de Melo for technical assistance.

\section{References}

1. Nigam SK, Aperia AC, Brenner BM. Development and maturation of the kidney. In: Brenner BM, Rector FC (Editors), The kidney: physiology and pathology. 5th edn. Philadelphia: WB Saunders; 1996. p 72-98.

2. Reeves W, Caulfield JP, Farquhar MG. Differentiation of epithelial foot processes and filtration slits: sequential appearance of occluding junctions, epithelial polyanion, and

slit membranes in developing glomeruli. Lab Invest 1978; 39: $90-100$.

3. Balbi AP, Costa RS, Coimbra TM. Postnatal renal development of rats from mothers that received increased sodium intake. Pediatr Nephrol 2004; 19: 1212-1218.

4. Roberts $A B$, McCune BK, Sporn MB. TGF-beta: regulation of extracellular matrix. Kidney Int 1992; 41: 557-559. 
5. Thiery JP, Duband JL, Dufour S, Savagner P, Imhof BA. Role of fibronectins in embryogenesis. In: Mosher D (Editor), Biology of extracellular matrix: fibronectin. San Diego: Academic Press, Inc.; 1989. p 181-212.

6. Kagami S, Border WA, Miller DE, Noble NA. Angiotensin II stimulates extracellular matrix protein synthesis through induction of transforming growth factor-beta expression in rat glomerular mesangial cells. J Clin Invest 1994; 93: 2431 2437.

7. Bagby SP, Holden W. Angiotensin II stimulates proliferation of aortic endothelial cells. Clin Res 1988; 36: 259A.

8. Carey AV, Carey RM, Gomez RA. Expression of alphasmooth muscle actin in the developing kidney vasculature. Hypertension 1992; 19: II-168-II-175.

9. Naruse K, Fujieda M, Miyazaki E, Hayashi Y, Toi M, Fukui $\mathrm{T}$, et al. An immunohistochemical study of developing glomeruli in human fetal kidneys. Kidney Int 2000; 57: 18361846.

10. Omori S, Hida M, Ishikura K, Kuramochi S, Awazu M. Expression of mitogen-activated protein kinase family in rat renal development. Kidney Int 2000; 58: 27-37.

11. Johnson RJ, lida H, Alpers CE, Majesky MW, Schwartz SM, Pritzi $P$, et al. Expression of smooth muscle cell phenotype by rat mesangial cells in immune complex nephritis. Alphasmooth muscle actin is a marker of mesangial cell proliferation. J Clin Invest 1991; 87: 847-858.

12. Bokemeyer D, Sorokin A, Dunn MJ. Multiple intracellular MAP kinase signaling cascades. Kidney Int 1996; 49: 11871198.

13. Balbi AP, Costa RC, Coimbra TM. Mitogen-activated protein kinases and angiotensin II expression in renal cortex of offspring from mothers submitted to increased salt intake. $J$ Am Soc Nephrol 2004; 15: 416A (Abstract).

14. Kubo T, Ibusuki T, Chiba S, Kambe T, Fukumori R. Mitogenactivated protein kinase activity regulation role of angiotensin and endothelin systems in vascular smooth muscle cells. Eur J Pharmacol 2001; 411: 27-34.

15. Choi BM, Yoo KH, Bae IS, Oh MH, Hong YS, Lee JW, et al. Angiotensin-converting enzyme inhibition modulates mitogen-activated protein kinase family expressions in the neonatal rat kidney. Pediatr Res 2005; 57: 115-123.

16. Woolf AS, Winyard PJ. Advances in the cell biology and genetics of human kidney malformations. J Am Soc Nephrol 1998; 9: 1114-1125.

17. Gomez RA, Lynch KR, Sturgill BC, Elwood JP, Chevalier $\mathrm{RL}$, Carey RM, et al. Distribution of renin mRNA and its protein in the developing kidney. Am J Physiol 1989; 257: F850-F858.

18. Gomez RA, Tufro-McReddie A, Everett AD, Pentz ES. Ontogeny of renin and AT1 receptor in the rat. Pediatr Nephrol 1993; 7: 635-638.

19. Millan MA, Carvallo P, Izumi S, Zemel S, Catt KJ, Aguilera G. Novel sites of expression of functional angiotensin II receptors in the late gestation fetus. Science 1989; 244 : 1340-1342.

20. Tufro-McReddie A, Harrison JK, Everett AD, Gomez RA. Ontogeny of type 1 angiotensin II receptor gene expression in the rat. J Clin Invest 1993; 91: 530-537.

21. Grady EF, Sechi LA, Griffin CA, Schambelan M, Kalinyak JE. Expression of AT2 receptors in the developing rat fetus. J Clin Invest 1991; 88: 921-933.
22. Yosypiv IV, Schroeder M, El-Dahr SS. Angiotensin II type 1 receptor-EGF receptor cross-talk regulates ureteric bud branching morphogenesis. J Am Soc Nephrol 2006; 17: 1005-1014.

23. Gribouval O, Gonzales M, Neuhaus T, Aziza J, Bieth E, Laurent $\mathrm{N}$, et al. Mutations in genes in the renin-angiotensin system are associated with autosomal recessive renal tubular dysgenesis. Nat Genet 2005; 37: 964-968.

24. Niimura F, Labosky PA, Kakuchi J, Okubo S, Yoshida H, Oikawa $\mathrm{T}$, et al. Gene targeting in mice reveals a requirement for angiotensin in the development and maintenance of kidney morphology and growth factor regulation. J Clin Invest 1995; 96: 2947-2954.

25. Kumar D, Menon V, Ford WR, Clanachan AS, Jugdutt BI. Effect of angiotensin II type 2 receptor blockade on mitogen activated protein kinases during myocardial ischemia-reperfusion. Mol Cell Biochem 2004; 258: 211-218.

26. Yang D, Tournier C, Wysk M, Lu HT, Xu J, Davis RJ, et al. Targeted disruption of the MKK4 gene causes embryonic death, inhibition of c-Jun NH2-terminal kinase activation, and defects in AP-1 transcriptional activity. Proc Natl Acad Sci U S A 1997; 94: 3004-3009.

27. Hida M, Omori S, Awazu M. ERK and p38 MAP kinase are required for rat renal development. Kidney Int 2002; 61: 1252-1262.

28. Xia Z, Dickens M, Raingeaud J, Davis RJ, Greenberg ME. Opposing effects of ERK and JNK-p38 MAP kinases on apoptosis. Science 1995; 270: 1326-1331.

29. Nicolantonio RD, Spargo S, Morgan TO. Prenatal high salt diet increases blood pressure and salt retention in the spontaneously hypertensive rat. Clin Exp Pharmacol Physiol 1987; 14: 233-235.

30. da Silva AA, de Noronha I, de Oliveira I, Malheiros DM, Heimann JC. Renin-angiotensin system function and blood pressure in adult rats after perinatal salt overload. Nutr Metab Cardiovasc Dis 2003; 13: 133-139.

31. Hazon N, Parker C, Leonard R, Henderson IW. Influence of an enriched dietary sodium chloride regime during gestation and suckling and post-natally on the ontogeny of hypertension in the rat. J Hypertens 1988; 6: 517-524.

32. Marin EC, Balbi AP, Francescato HD, Alves da Silva CG, Costa RS, Coimbra TM. Renal structure and function evaluation of rats from dams that received increased sodium intake during pregnancy and lactation submitted or not to 5/ 6 nephrectomy. Ren Fail 2008; 30: 547-555.

33. Daikha-Dahmane F, Levy-Beff E, Jugie M, Lenclen R. Foetal kidney maldevelopment in maternal use of angiotensin II type I receptor antagonists. Pediatr Nephrol 2006; 21: 729-732.

34. Spence SG, Zacchei AG, Lee LL, Baldwin CL, Berna RA, Mattson BA, et al. Toxicokinetic analysis of losartan during gestation and lactation in the rat. Teratology 1996; 53: 245252.

35. Spence SG, Allen HL, Cukierski MA, Manson JM, Robertson RT, Eydelloth RS. Defining the susceptible period of developmental toxicity for the AT1-selective angiotensin II receptor antagonist losartan in rats. Teratology 1995; 51: 367-382.

36. Akil I, Inan S, Gurcu B, Nazikoglu A, Ozbilgin K, Muftuoglu S. Histopathological and ultrastructural effects of losartan on embryonic rat kidney. Acta Histochem 2005; 107: 291300 . 
37. Friberg $P$, Sundelin $B$, Bohman SO, Bobik A, Nilsson $H$, Wickman $A$, et al. Renin-angiotensin system in neonatal rats: induction of a renal abnormality in response to ACE inhibition or angiotensin II antagonism. Kidney Int 1994; 45: 485-492.

38. Chen Y, Lasaitiene D, Gabrielsson BG, Carlsson LM, Billig $\mathrm{H}$, Carlsson B, et al. Neonatal losartan treatment suppresses renal expression of molecules involved in cell-cell and cell-matrix interactions. J Am Soc Nephrol 2004; 15: 1232-
1243.

39. Machado FG, Poppi EP, Fanelli C, Malheiros DM, Zatz R, Fujihara CK. AT1 blockade during lactation as a model of chronic nephropathy: mechanisms of renal injury. Am $J$ Physiol Renal Physiol 2008; 294: F1345-F1353.

40. Balbi AP, Marin EC, Francescato HD, Costa RS, Coimbra TM. MAPK and angiotensin II receptor in kidney of newborn rats from losartan-treated dams. Pediatr Nephrol 2008; 23: 1433-1444. 